\title{
In memoriam Alan S. Milward (1935-2010)
}

With deep gratitude we bid farewell to Alan Milward. The great British economic and European historian, member of the EU Liaison Committee of Historians since its foundation in 1982, passed away on 28 September 2010.

The work of Alan Milward has enriched historical research in manifold ways. Broad horizons that transcended again and again national standpoints and the selfdefined limits of the disciplines, combined with his readiness to pursue an intensive study of sources in the most varied archives and languages and his inclination to develop explicit and sometimes provocative theses, all this made him become a genuine European historian, who has contributed substantially to the understanding of European history since the age of National Socialism.

These qualities have become plain already in his first major work The German Economy at War (published in 1965), where Milward pointed out that, already before the outbreak of World War II, the German economy had been a War economy and that German politics therefore were clearly heading for war. At the same time he described the German strategy of warfare as economically sound: Blitzkriege against single weaker enemies were meant to supply the German Reich with the resources necessary for each next step of expansion. Studies of the modus operandi of the German occupying forces in France (The New Order and the French Economy, 1970) and Norway (The Fascist Economy in Norway, 1972) showed how the economic exploitation of the occupied areas was working. National Socialist Germany could thus pursue a consumer friendly policy, which sustained war morale and avoided the collapse of the internal front, a risk, which Hitler was continuously worrying about. Milward provided with that work a key to the understanding of Hitler's rule over Europe, its genesis and its long duration.

In War, Economy and Society 1939-1945 (first published in German language in 1978, followed afterwards by an English, Italian and Spanish version) he integrated these former findings into a general account of the economic and societal developments during the time of World War II, which included all countries of the European continent, independently of their position in this war. Implicitly he thus made also aware of the consequences of the war that went beyond the shifts occurring on a purely power political level: another disintegration of economic equilibriums, the unproductive destruction of resources and the manifold destabilization of societies. The complex economic and societal realities at the end of the war, hiding behind the sweeping cliché of the Stunde Null, the new starting point of a war-torn Europe, have thus been brought to the attention of historians for the first time.

So in his following major work The Reconstruction of Western Europe, 1945-51 (1984), Alan Milward was well prepared for investigating on a realistic basis the genesis of the postwar boom and analyzing critically the reconstruction policy of the USA and the European Governments. In the process he reached two fundamental theses, which greatly influenced the discussion on the construction of post-war Eu- 
rope: on the one hand he argued that from a purely macro-economic point of view the Marshall plan had been unnecessary. When American help arrived, the European countries were already on the way of recovery; the means of the Marshall plan just accelerated it. On the other hand, Milward showed that often strong national interests were hiding behind the European policy that led to the European Coal and Steel Community (ECSC): With the Schuman Plan France wanted to back the reconstruction strategy that was based on the control of West-Germany's resources; Belgium depended upon support for the modernization of its ailing coal-mining industry.

By carrying out fundamental research on the reconstruction of Western Europe, Milward entered the field of European integration history. After having held since 1971 a chair of European Studies at the University of Manchester, he was offered the chair of European contemporary history at the European University Institute (EUI) in Florence in 1983. In the year 1986 he was appointed to the chair of economic history at the London School of Economics. He accepted for a second term, from 1996 to 2002, the chair in Florence, which he combined in the end with the position of an "Official Historian" of the British government for research on the British European policy.

During the time of his first residence in Florence, he integrated the findings of his study of the Schuman Plan into a general thesis: In controversy with the neo-functionalist theory of the integration of nation-states and the official mystification of the founding fathers of the European communities, he considered European integration as an instrument that assisted weakened nation-states in coping with problems of national welfare. National governments resorting to this instrument secured in this way their legitimacy towards their citizens and contributed to reassert the principle of the nation- state. Milward called this The European Rescue of the Nation-State and triggered off a fierce debate with a book published in 1992 under the same title.

As an Official Historian of the British Government Milward wrote a comprehensive history of the British European policy between 1945 and 1963, and, in his utilization of internal documents, he went far beyond that, what had been possible up to then in other member states of the EU (The Rise and Fall of a National Strategy 1945-1963, published in 2002). In the process he extended once again his field of study: In addition to the economic and welfare aspects he also analyzed the geopolitical conditions of a, how he put it, "small, rich country with a medium-sized economy", which had overstrained itself during war and had at its disposal an "extensive, but poor, colonial empire". At the same time he reassessed his methodical approach by making a shift in emphasis: Following on from his former studies of the National Socialist politics, he now tried to identify national strategies, which were developed by responsible politicians in engagement with divergent opinions and competing influences. According to his new wording, these national strategies had a greater influence, at least until 1963, on the creation and the development of the European Communities than the European movement.

Milward's theses have always been open to dispute. Particularly the provocative slogan of the "European Rescue of the Nation-State" was considered by many critics 
as too one-sided. It was also frequently misunderstood as a claim for a pure intergovernmental understanding of the European construction. Though he liked resorting to pointed emphasis, Milward nevertheless has always remained a seeker, left unsatisfied by his own answers and looking out for better explanations in dialogue. He has stimulated research through his many suggestions and he for his part also took up in his works proposals of colleagues and students. To a large extent, the credit belongs to him that research on the history of European integration has been developing so dynamically for the last 30 years, not thanks to the striving of historians for personal distinction or delimitation, but thanks to constructive dialogue. With his acute analyses he has also helped the science of history gain attention and credit among the theorists of European integration as well as among the practitioners of European integration policy.

It fits the picture that Alan Milward has been one of the most reliable members of the EU Liaison Committee of Historians. From the creation of the Committee in January 1982 up to his tragic illness in October 2007 he had not missed one single meeting of the group. At international conferences, organized by the Committee, his contributions used to be highly valued; he himself had organized one important conference together with Anne Deighton (Widening, Deepening and Acceleration: The European Economic Community 1957-1963, published in 1999). He was an extremely congenial and positive colleague, always well informed, with plenty of wise ideas, but modest through and through, endowed with an unflaggingly inquiring mind. We hold him in high esteem and we miss him very much. We are grateful that we may have shared his friendship. 
nttps://doi.org/10.5771/0947-9511-2010-2-5

Generiert durch IP '172.22.53.54', am 26.04.2023, 11:35:34.

Das Erstellen und Weitergeben von Kopien dieses PDFs ist nicht zulässig. 


\section{Preface}

\section{Ambitions and Reality of the Common Agricultural Policy: Historical and Interdisciplinary Perspectives}

\section{Carine GERMOND/Katja SEIDEL/Mark SPOERER}

It is a paradox that since its beginnings in the 1950s the European integration process has been closely tied to agriculture - a sector in decline. The Common Agricultural Policy (CAP) became the European Community's (EC) first common policy and it was and still is its most expensive single budget item. Due to the annual price negotiations and the important surpluses that emerged already in the mid-1960s - often caricatured as butter mountains and milk lakes - the CAP was by far the most visible and the most contested EC policy. Conversely, repeated attempts to reform the policy over a period of more than two decades failed to bring about the required corrections. ${ }^{1}$

As the CAP has turned around billions of euro scholars have studied the policy and published expertises, analyses and studies since its inception. This engagement led to a number of valuable syntheses by economists, sociologists and political scientists. ${ }^{2}$ Historians have only recently started to become interested in the CAP.

These historians usually do not have a background in agricultural history. It was rather the interest in the European integration process that brought the beginnings of the CAP into the focus of historical research. The importance some member states attributed to a common agricultural policy and the subsequent efforts by the European Commission of designing the policy may explain why studying the CAP became necessary when analysing the early phase of European integration. The ever-increasing expenditure for the CAP in the EC budget was another factor which meant that no serious history of the beginnings of the European integration process could evade agriculture. ${ }^{3}$ Hence, historical accounts have so far focused on the 'Pool Vert', a plan

1. The authors are grateful to the German Historical Institute Paris for generous financial support of their research.

2. See, for example, B.E. HILL, The Common Agricultural Policy: Past, Present and Future, Methuen, London, 1984; E. NEVILLE-ROLFE, The Politics of Agriculture in the European Community, Policy Studies Institute, London, 1984; R. FENNELL, The Common Agricultural Policy: Continuity and Change, Clarendon, Oxford, 1997; A. KAY, The Reform of the Common Agricultural Policy: The Case of the MacSharry Reforms, CABI Publ., Wallingford, 1998; E. FOUILLEUX, La Politique agricole commune et ses réformes: une politique à l'épreuve de la globalisation, L'Harmattan, Paris, 2003; I. GARZON, Reforming the Common Agricultural Policy: History of a Paradigm Change, Palgrave/Macmillan, Basingstoke, 2006.

3. See A.S. MILWARD, The European Rescue of the Nation State, Routledge, London, 1992, chapter 5; A. MORAVCSIK, The Choice for Europe: Social Purpose and State Power from Messina to Maastricht, UCL Press, London, 1998, chapters 3 and 4; N.P. LUDLOW, The European Community and the Crises of the 1960s: Negotiating the Gaullist Challenge, Routledge, Abingdon, 2006; and most 